\title{
Resolving Contradictions: Samuel Hirsch and The STAKes OF Modern JeWish Thought Robert Erlewine
}

\begin{abstract}
This essay treats the contradictions that beset Samuel Hirsch's Die Religionsphilosophie der Juden in order to clarify the nature of the study of modern Jewish thought. I begin by examining how Emil Fackenheim presents the contradiction in Hirsch's thought as evidence of the incompatible assumptions underlying dominant strands of modern philosophy and "authentic" Jewish theology. Agreeing with Fackenheim that Hirsch's work is contradictory, this essay diverges on both the nature of this contradiction and its implications for Jewish thought. I claim that the argument of Die Religionsphilosophie der Juden founders as a result of Hirsch's refusal to choose between three different, and ultimately incompatible, strategies for articulating the relationship between God and human beings. I then conclude by exploring the implications of the collapse of Hirsch's position with regard to the dispute between theocentrists and ethical monotheists and for the field of modern Jewish thought more broadly.
\end{abstract}

The effort to discern what is authentically Jewish and to distinguish it from syncretistic borrowings or assimilationist dilutions has been central to the project of modern Jewish thought. ${ }^{1}$ In recent years, in line with developments in religious studies, scholars have become increasingly suspicious of the ideological underpinnings of such endeavors. ${ }^{2}$ And yet, while the appeal to authenticity may be methodologically problematic, it has nevertheless been frequently employed in central debates in modern Jewish thought.

If we turn to one of the major fault lines in twentieth-century Jewish thought, how to conceptualize the relationship between human beings and God, appeals to authenticity can be seen to play a prominent role. One line of thinking in this dispute, what I will call theocentrism - in this camp one could include the work of thinkers as diverse as Martin Buber, Franz Rosenzweig, Abraham Joshua Heschel, Emil Fackenheim, and Michael Wyschogrod-presents "genuine" or "authentic" Judaism as revolving around the notion of covenant. For theocentrists, the lived relationship with God, both in terms of the individual and for the Jewish

1. I would like to thank Jacqueline Paskow, Dustin N. Atlas, and Martin Kavka for their assistance and thoughtful suggestions at various stages of the formulation and revision of this essay.

2. See, for instance, Aaron W. Hughes, Rethinking Jewish Philosophy: Beyond Particularism and Universalism (Oxford: Oxford University Press, 2014). For an influential work about this issue with regard to the discipline of religious studies, see Russell McCutcheon, Manufacturing Religion: The Discourse on Sui Generis Religion and the Politics of Nostalgia (Oxford: Oxford University Press, 2003). 


\section{Robert Erlewine}

people as a whole, is, and indeed must be, the heart of any legitimate Jewish theology. In contrast, the standpoint of ethical monotheism - as characterized by such figures as Hermann Cohen, Leo Baeck, Kaufmann Kohler, and Emmanuel Levinas-insists that Judaism's distinctiveness lies with its ethical focus, which these thinkers argue is rooted in a certain conception of God. For this position, God is not encountered or engaged directly. Indeed, the religious significance of the ethical is rooted in God's distance, in God's palpable absence from human experience. While theocentrism and ethical monotheism characterize Judaism in starkly different terms, thinkers in both camps present their arguments as articulating the distinctive or authentic essence of Judaism.

It is in the context of this debate that I will turn to the thought of Samuel Hirsch (1815-1889), in particular his Die Religionsphilosophie der Juden (1842). ${ }^{3}$ To be sure, this work has a rather marginal position in the contemporary study of modern Jewish thought and has justly been criticized for being contradictory. Yet, it presents arguments that anticipate the central claims of both the theocentrists and ethical monotheists. By attending to the tensions internal to Hirsch's thought, we will be able to better understand the stakes of this twentieth-century debate.

\section{Emil L. Fackenheim, Samuel Hirsch, and the Dilemma of Modern Jewish Thought}

In essays and books that span the 1950s through the early 1970s, Emil L. Fackenheim argues that modern (European and Anglo-American) philosophy operates with certain basic assumptions that are incompatible with the central

3. Samuel Hirsch, Die Religionsphilosophie der Juden oder das Prinzip der jüdischen Religionsanschaunng und sein Verhältniss zum Heidenthum, Christenthum und zur absoluten Philosophie dargestellt und mit den erläuterten Beweisstellen aus der heiligen Schrift, den Talmudim und Midraschim versehen (Leipzig: Heinrich Hunger, 1842). I will include the original language in the notes after each quotation. For a partial translation, with biography, analyses, and summary of the translated texts, see Gershon Greenberg, ed. and trans., "Samuel Hirsch (1815-1889): Consciousness and Freedom," in Modern Jewish Thinkers: From Mendelssohn to Rosenzweig (Brighton, MA: Academic Studies Press, 2011), 171-204. For biographical information about Hirsch, see Elmar R. Ittenbach, "Geboren in Thalfang: Samuel Hirsch einer bedeutendsten jüdischen Denker," in Jüdisches Leben in Thalfang: Geschichte und Shicksale (Trier: Paulinius, 2011), and Ittenbach, Samuel Hirsch: Rabbinical-Religionsphilosoph-Reformer (Berlin: Hentrich und Hentrich, 2014). While I will only discuss Die Religionsphilosophie der Juden in this essay, it should be noted that during this period Hirsch also published sermons and wrote for periodicals. These writings appear in Samuel Hirsch, Friede, Freiheit und Einheit (Dessau: Hermann Neuberger, 1839) and Die Messiaslehre der Juden (Leipzig: H. Hunger, 1843). For an insightful discussion of Hirsch's work from this period, see Gershon Greenberg, "Samuel Hirsch in Dessau (June 1838-June 1843): Freedom, Emancipation, and the Jewish State," in Samuel Hirsch: Religionsphilosoph, Emanzipationsverfechter und radikaler Reformer: Juedische Identitaet im 19. Jahrhundert am Beispeil von Werk und Wirkung der ersten Oberrabbiner Luxembourg, ed. Judith Frischman and Christian Wiese (forthcoming). 
foundations of Jewish theology. ${ }^{4}$ In these works, Immanuel Kant's thought, particularly its presentation of divine agency and revelation as incompatible with human freedom, is taken as emblematic of the views of modern philosophy. ${ }^{5}$ At the same time, Fackenheim maintains that the notions of revelation and divine agency are fundamental to Jewish theology. As a result, in Fackenheim's estimation, modern Jewish thought is caught on the horns of a serious dilemma-or rather dilemmas, in that he formulates several closely related iterations in the essays that make up Quest for Past and Future - because the foundational commitments of Jewish theology and modern philosophy are incompatible. ${ }^{6}$ As a result, Fackenheim calls for Jewish thought to cast off the Kantian framework of so much modern philosophy in favor of the dialogical existentialism of Martin Buber and Franz Rosenzweig. ${ }^{7}$

4. Emil L. Fackenheim, Quest for Past and Future: Essays in Jewish Theology (Bloomington: Indiana University Press, 1968), and Fackenheim, Encounters between Judaism and Modern Philosophy (New York: Basic Books, 1973; Northvale, NJ: Jason Aronson, 1994).

5. For a discussion of the role of Kant in Fackenheim's thought during this period, see Michael L. Morgan, Fackenheim's Jewish Philosophy: An Introduction (Toronto: University of Toronto Press, 2013), 82-130.

6. In various essays in Quest for Past and Future, Fackenheim presents three related and overlapping theoretical dilemmas facing liberal Judaism. In "Can There Be Judaism without Revelation," Fackenheim presents the following dilemma for those who want to maintain some sense that human beings can "receive a revelation" while also maintaining modern philosophical sensibilities. He writes, "Either revelation discloses what man may discover by means lying within his own powers - but then it is superfluous; or else it discloses what lies beyond human means of discovery - but then it would seem to lie beyond human comprehension too, and the recipient of a revelation could not understand it" (67-68). That is, given the foundations of modern thought, the notion of revelation can fit only if it is "either superfluous or senseless" (68). In other words, "Either we know the will of God by our own ability, potentially if not actually - in which case we require only a philosopher such as Socrates but not a prophet; or else we are unable to learn it, even through the mouth of a prophet" (68). More salient for our concerns here are the two formulations with regard to the notion of autonomy, so central to liberal accounts of Judaism. In "The Dilemma of Liberal Judaism," Fackenehim claims that autonomy, when actualized, is a state of "creative self-realization" incompatible with "all passivity and receptivity" (134). As a result, he insists, "only two possibilities therefore remain concerning revelation if man is capable of autonomy. Either God does not contact man at all, being nonexistent or necessarily absent. Or else the God who contacts man is not other than man and present to man, but rather present in man. Revelation occurs, in that case, in great moments of human self-realization and is identical with it. Religious experience, or moral conscience, are not stimulated or caused by God. They are themselves divine" (134). Regardless of what we choose, the possibility for genuine encounter, the foundation of Jewish notions of covenant and revelation, is eliminated. In "The Revealed Morality of Judaism and Modern Thought," Fackenheim reformulates this dilemma in terms of the incompatibility of Kantian morality with a notion of divine command, which he takes to be foundational for Judaism. I present this particular formulation in the body of the essay.

7. Indeed, in Fackenheim's - rather hyperbolic — estimation, "the whole future of Jewish theology is at stake" (Quest for Past and Future, 4) in the shared effort of Martin Buber and Franz Rosenzweig to provide a "radical Jewish response" to the assumptions of modern philosophy, searching for "nothing less than a modern presence of the ancient God" (5). That is, the project of Buber and Rosenzweig is so vital for Fackenheim because while they maintain the integrity of reason, facing the implications of the historical critical approach to the Bible, they nevertheless refuse to accept the central assumption Fackenheim takes to underlie modern philosophy, namely, the rejection of any possible meaningful encounter between God and human beings. 


\section{Robert Erlewine}

In "The Revealed Morality of Judaism and Modern Thought," Fackenheim argues that the notion of autonomy, so central to Kant's ethics, is incompatible with Judaism's understanding of morality, which he argues is rooted in revelation and divine law. As a result, Fackenheim avers, Kant's thought leaves the "believer in revealed morality," that is, the Jew, with an impossible dilemma. "Either [the believer in revealed morality] concedes that the will can and must impose the Godgiven law upon itself; but then its God-givenness becomes irrelevant in the process of self-imposition and appropriation; or else he insists that the God-givenness of the law does not and cannot at any point become irrelevant; but then the will cannot impose the law on itself-it can only submit to it for such non-moral reasons as trust in divine promises or fear of divine threats." ${ }^{8}$ Insofar as Kant presents genuine human agency and divine intervention as mutually exclusive, his thought eliminates the possibility of a meaningful notion of revelation. In the terms laid out by Kant, God can only be conceived of as either utterly overwhelming or entirely irrelevant. Such a view is incompatible with authentic Jewish theology, which, Fackenheim maintains, is predicated on a give-and-take between God and human beings, where God's revelation must be answered, and answered freely.

As Fackenheim understands it, a philosophically inclined Jew who accepts the basic terms of the framework that Kant presents is forced into a dire choice: either revelation and tradition or ethics and reason, either Judaism or modernity. This either/or leads to the flawed alternatives - in Fackenheim's estimation at least - of Jewish orthodoxy and Jewish liberalism, which, because they accept the terms Kant sets out, are forced to choose one option at the expense of the other. Orthodoxy seeks to preserve a robust account of God and tradition by evading reason, relegating God's agency "to a conveniently remote Biblical and Talmudic past, [and] acting as though the sacred documents of that past could be exempted from modern criticism." ${ }^{.9}$ On the other hand, in Fackenheim's estimation, liberal Judaism makes a devastating concession to modern philosophy, "compromis[ing] the Jewish God Himself." 10 Fackenheim clearly finds neither alternative to be tenable.

In a footnote appended to the quote regarding the "dilemma" that Kant's ethics poses for the adherent of revealed morality, Fackenheim mentions Samuel Hirsch, that "remarkable nineteenth century Jewish thinker." Hirsch uniquely embodies this dilemma for Fackenheim because he both holds fast to "Kantian autonomous morality" while also "believ[ing] quite literally in revelation." $" 11$ To be sure, Fackenheim grants that Hirsch is "aware of the possibility

8. Fackenheim, "The Revealed Morality of Judaism and Modern Thought," in Quest for Past and Future, 214.

9. Fackenheim, Quest for Past and Future, 5.

10. Ibid. While the ethical monotheist position is most often associated with liberal Judaism, including such luminaries of Reform Judaism as Hermann Cohen, Leo Baeck, and Kaufmann Kohler in its ranks, it is worth mentioning that the most prominent recent exponent of this position, Emmanuel Levinas, identified with Orthodox Judaism.

11. Ibid., 328 . 


\section{Resolving Contradictions}

of conflict" between these two commitments but Fackenheim finds that Hirsch's attempt to resolve it is unsuccessful. ${ }^{12}$

Fackenheim presumably judges Hirsch to be remarkable because unlike other thinkers who aligned with either orthodoxy or liberalism he seems to reject this dilemma. In this reading, then, Hirsch embraces an emphasis on reason while also recognizing the centrality of divine revelation for Jewish theology. In Fackenheim's estimation, then, Hirsch's thought is uniquely instructive precisely because it seeks to develop an "authentic" Jewish theology within the framework of modern philosophy rather than settle for only one alternative, like orthodoxy and liberalism. It is, of course, for this very reason, doomed to fall into contradiction. But from its failure, Fackenheim thinks, Jewish thought can learn to renegotiate the terms set by modern philosophy.

This footnote by Fackenheim, which formulates Hirsch's philosophical project in terms of an entanglement with a decidedly Kantian problematic, is intriguing. It is worth mentioning that in the sizable scholarly reception of Die Religionsphilosophie der Juden, ${ }^{13}$ Fackenheim is not the only scholar to remark on

12. Fackenheim, Quest for Past and Future, 328, notes that Hirsch attempts to "resolve" this contradiction "by interpreting revelation (following Lessing) as divine education toward moral autonomy." He continues, "Hirsch's ingenuity in developing this doctrine does not save it from ultimate failure. Revelation here is a divine guidance the sole purpose of which is to emancipate man from the need for guidance, and hence from revelation itself." Fackenheim concludes the note by referencing his essay from 1964 devoted to Hirsch, "Samuel Hirsch and Hegel" (originally published in Studies in Nineteenth-Century Jewish Intellectual History, ed. Alexander Altmann [Cambridge, MA: Harvard University Press, 1964] and republished in Jewish Philosophers and Jewish Philosophy, ed. Michael L. Morgan [Bloomington: Indiana University Press, 1996], 21-40).

13. Die Religionsphilosophie der Juden has been discussed in several important surveys of Jewish philosophy. It is occasionally discussed in terms of the history of Reform Judaism, and there have been a handful of scholarly essays devoted to it. With regard to surveys of Jewish thought, see Julius Guttmann, Die Philosophie des Judentums (Munich, 1933) translated by David W. Silverman, Philosophies of Judaism (New York: Holt, Rinehart and Winston, 1964), 313-21; Max Wiener, Jüdische Religion im Zeitalter der Emanzipation (Berlin: Philo, 1933), 131-47; H. J. Schoeps, Geschichte der jüdischen Religionsphilosophie der Neuzeit (Berlin: Vortrupp, 1935), 93-132; Nathan Rotenstreich, Jewish Philosophy in Modern Times (New York: Holt, Rinehart and Winston, 1968), 120-36; Eliezer Schweid, A History of Modern Jewish Religious Philosophy, vol. 2, The Birth of Historical Studies and the Modern Jewish Religious Movements, trans. Leonard Levin (Leiden: Brill, 2015), 69-91. With regard to the Reform Movement, see Gershon Greenberg, "Religionswissenschaft and Early Reform Jewish Thought: Samuel Hirsch and David Einhorn," in Modern Judaism and Historical Consciousness, ed. Andreas Gotzmann and Christian Wiese (Leiden: Brill, 2007), 110-44; Michael Meyer, "Reform Jewish Thinkers in Their German Intellectual Context," in The Jewish Response to German Culture: From Enlightenment to the Second World War, ed. Jehuda Reinharz and Walter Schatzberg (Hanover, NH: University Press of New England, 1985), 64-84; Meyer, Response to Modernity: A History of the Reform Movement in Judaism (Detroit, MI: Wayne State University Press, 1995), 72-74; and Christian Wiese, "Von Dessau nach Philadelphia: Samuel Hirsch als Philosoph, Apologet und radikaler Reformer," in Jüdische Bildung und Kultur in Sachsen-Anhalt von der Aufklärung bis zum Nationalsozialismus, ed. Giuseppe Veltri and Christian Wiese (Berlin: Metropol, 2008). In terms of essays focusing on this work exclusively, or at least which devote significant attention to it, see Gershon Greenberg, "Samuel Hirsch: Jewish Hegelian," Revue des études juives 129 (1970): 205-15; Greenberg, "Religion and History according to Samuel Hirsch," Hebrew Union College Annual (1972): 


\section{Robert Erlewine}

Hirsch's debt to Kant, ${ }^{14}$ although it is Hirsch's connection with Hegel and neoHegelians that has received the most attention from commentators, including by Fackenheim himself, in his important essay "Samuel Hirsch and Hegel," which he cites in the same footnote. That Fackenheim formulates Hirsch's thought explicitly in Kantian terms in this footnote sheds light on the stakes of Fackenheim's earlier work on Hirsch. In this essay, where Kant is hardly mentioned, Fackenheim also presents Hirsch's thought as riven by contradiction. ${ }^{15}$ The emphasis on the radicality of human freedom here emerges from a desire to outflank Hegel's attempt to sublate the distinction between God and human beings in religion. Yet, Fackenheim finds that Hirsch's efforts to philosophically reconstruct the Jewish tradition, because they recognize that authentic Jewish theology requires a commitment to God's agency, cannot remain within the confines of the purely human and purely moral conception of religion that he develops to avoid falling into Hegel's dialectic. Just as in the footnote, then, "Samuel Hirsch and Hegel" presents Hirsch's thought as collapsing as a result of the desire to hold two incompatible commitments, a conception of human agency rooted in radical freedom on the one hand, and the agency of God on the other. In this reading, Hirsch's commitment to authentic Jewish theology, then, leads to the collapse of his carefully constructed philosophical position.

In what follows, I seek to offer an alternate reading of Hirsch's Die Religionsphilosophie der Juden to that provided by Fackenheim, arguing that Hirsch's position is, in fact, even more contradictory than Fackenheim acknowledged. Where Fackenheim finds Hirsch's thought to be caught between its incompatible commitments to modern philosophy and Jewish theology, I argue that Hirsch's thought actually maintains three distinct and mutually exclusive strategies for reconciling human freedom with divine agency. Hirsch's thought falls into contradiction not because the presuppositions of modern philosophy are incompatible with authentic Jewish theology, but rather because Hirsch refuses to choose between the range of strategies for reconciling human freedom and divine agency available to him. If I am correct, then, the collapse of Hirsch's position into contradiction reveals not that the dialogical philosophies of Buber and Rosenzweig somehow more authentically accord with Jewish theology than those philosophies influenced by Kant's critical idealism. Rather, it indicates that there are numerous possible strategies available for articulating the insights of Jewish theology in a modern philosophical idiom. In this reading, then, the question for Jewish thought that Hirsch's work exemplifies is not so much whether Jewish theology can be squared with modern philosophy, but rather, whether the range of possible philosophical articulations of Jewish thought can be squared with one another.

103-24; Fackenheim, "Samuel Hirsch and Hegel"; and Manfred Vogel, "Does Samuel Hirsch Anthropologize Religion,” Modern Judaism 1, no. 3 (Dec. 1981): 298-322.

14. Guttmann, Philosophies of Judaism, 316, points out that Hirsch's notion of freedom is much closer to Kant and Fichte than to Hegel. In A History of Modern Jewish Religious Philosophy, 73-74, Schweid emphasizes the role of Kant with regard to Hirsch's notion of freedom.

15. For an insightful discussion of Fackenheim's essay on Hirsch, see Martin Kavka, "Strategies of Jewish Hegelianism: Emil Fackenheim and Samuel Hirsch” (unpublished manuscript). 


\section{Strategy 1: The Distant God}

In the first chapter of Die Religionsphilosophie der Juden, Hirsch lays out a position that tracks quite closely with ethical monotheism insofar as he seeks to define religion in purely human terms, as pertaining to the exercise of freedom by human beings. ${ }^{16}$ Hirsch insists that religion is not to be understood in terms of the relationship between human beings and God, but rather in terms of the relationship of human beings with themselves. To the degree human beings fulfill their capacity for freedom, they are religious. Freedom is to be understood, then, as "the essential and single true concept of religion. The religious life is nothing else than the eternal actual and eternally actualizing freedom."17

While scholars have long noted the anthropological thrust of this strategy, with some even likening it to that practiced by Hirsch's contemporary, Ludwig Feuerbach, God nevertheless remains an important component of Hirsch's position. ${ }^{18}$ Indeed, there is wide agreement among scholars that Hirsch's denial of a relationship between God and human beings in Die Religionsphilosophie der Juden is part of his strategy to break with Hegel, who collapses the distinction between God and human beings. ${ }^{19}$ Hegel grants that, at least initially, God is understood to be a being fundamentally different from humans within the representational thinking that inheres in religion. However, Hegel argues that in the transition from religion to philosophy, when representations give way to the logical development of concepts, the distinction between God and human beings is sublated. In contrast to Hegel's philosophy of religion, Hirsch develops an account of religion where God's transcendence is preserved, where God always remains different and distinct from human beings.

16. For a reading of Hirsch's thought as a forerunner to twentieth-century Jewish ethical monotheism, see Robert Erlewine, "Samuel Hirsch, Hegel, and the Legacy of Ethical Monotheism," Harvard Theological Review 113, no. 1 (January 2020): 89-110.

17. Hirsch, Die Religionsphilosophie der Juden, 13, "Das ist aber auch der wesentliche und einzig wahre Begriff von Religion. Das religiöse Leben ist gar nichts anderes, als diese ewig wirkliche und ewig sich verwirklichende Freiheit." Italics in original.

18. In their respective discussions of Hirsch, Hans Joachim Schoeps, in Geschichte der jüdischen Religionsphilosophie der Neuzeit, and Nathan Rotenstreich, in Jewish Philosophy in Modern Times, suggest that Hirsch's rejection of the possibility of a divine-human relationship is methodologically similar to the theological anthropology of Ludwig Feuerbach, and both interpret his account of revelation in terms of this rejection. For Schoeps, divine Otherness is eliminated from revelation, while Rotenstreich casts revelation in ontological rather than historical terms. In "Does Samuel Hirsch Anthropologize Religion," Manfred Vogel challenges, convincingly in my estimation, the appropriateness of likening Hirsch's argument in Die Religionsphilosophie der Juden to that of Feuerbach. For a discussion of Hirsch's later work, which does, in fact, move decisively in the anthropological direction that Schoeps and Rotenstreich mention, see Gershon Greenberg, "The Historical Origins of God and Man in Samuel Hirsch's Luxembourg Writings," Leo Baeck Institute Year Book 20 (1975): 129-48.

19. On the methodological significance of this move vis-à-vis Hegel, see Fackenheim "Samuel Hirsch and Hegel," 29-30; Rotenstreich, Modern Philosophies of Judaism, 124; and Schoeps, Geschichte der jüdischen Religionsphilosophie der Neuzeit, 106. 


\section{Robert Erlewine}

Fackenheim is quite correct to link Hirsch's strategy for preserving God's distinctive difference from human beings with Kant. In a line of thinking developed in the Critique of Practical Reason, ${ }^{20}$ one which will become quite prominent in Jewish ethical monotheist arguments, Kant insists that the notion of autonomy, central to the very capacity of human beings to fulfill their role as moral agents, can only function if God is understood to be radically transcendent. ${ }^{21}$ Kant thinks that if human beings were to actually possess some "capacity for insight" or "illumination" with regard to God's existence and will, the consequences would be dire. To be sure, if such capacity for insight, or illumination, were readily available, then we, human beings, would most certainly refrain from wrongdoing. Yet, for all that, we would not be moral. Rather, since "God and eternity with their dreadful majesty would lie unceasingly before our eyes," ${ }^{22}$ Kant concludes, "most lawful actions would be done from fear, only a few from hope, and none at all from duty." Only a distant God, an object of reasoned hope, which is not encountered or known directly, is compatible with the human being as moral agent. Consequently, the "moral worth of actions-on which alone, after all, the worth of the person and even that of the world hinges in the eyes of the highest wisdom-would not exist at all., ${ }^{23}$ Morality would cease as human beings would lack the freedom necessary for agency. In such circumstances, human activity, Kant suggests, would resemble nothing so much as "a puppet show ... [as] everything would gesticulate well but there would still be no life in the figures." 24

While Hirsch does not explicitly use the Kantian terminology of autonomy, he seeks to elucidate, at least in this first strategy, a conception of religion in line with it. Freedom, for Hirsch, is to be understood in terms of the radical independence of human beings in determining themselves. Or, as he puts it, "It is essential to the concept of freedom to owe everything to itself; because human beings should completely make themselves into what they are." 25 By insisting on the radical independence required for a genuine concept of freedom, Hirsch follows Kant in presenting God's radical transcendence as essential for the ethical development of human beings. With this strategy, Hirsch hopes to immunize his position against

20. Immanuel Kant, Critique of Practical Reason, trans. Werner S. Pluhar (Indianapolis, IN: Hackett, 2002).

21. Part of the enduring appeal of Kant to modern Jewish thinkers is that his thought insists that conceptions of God have moral implications. The ethical monotheist strand of Jewish thought embraces this strategy, using it to reinscribe the distinction between monotheism and idolatry. In the conclusion of this essay, I will briefly discuss Kant's influence on the ethical monotheist strand of modern Jewish thought.

22. Kant, Critique of Practical Reason, 185.

23. Ibid., 186.

24. Ibid.

25. Hirsch, Die Religionsphilosophie der Juden, 39. The full sentence from which my quote is taken is "Weil es dem Begriffe der Freiheit wesentlich ist, sich selbst Alles zu verdanken zu haben; weil der Mensch durchaus das erst aus sich machen soll, was er ist." Italics in the original. Some translations have been altered for clarity and inclusivity. 
Hegel's attempt to sublate the difference and distinction between God and human beings.

Hirsch provides an account of how human beings determine themselves through the paradoxical notion of the free choice for freedom. The framework for this choice is provided by rooting the human being in a metaphysical dualism, that between spirit and nature. The human being, as a composite of nature and spirit, is split at the root. While bound to corporeality, to the desires and instincts inherent in nature, what Hirsch terms Natürlichkeit, the human being is also a creature of spirit. God, understood as pure spirit, is conceived as irreducible to and lord over nature. Human beings are neither wholly spiritual nor wholly natural, and thus, as torn between these two antagonistic elements, must choose how to constitute themselves, namely, either as free beings like God or as animals propelled by irresistible drives and impulses. Human beings, whose essence, or perhaps better, whose telos, resides in the actualization of freedom, can only realize this telos if there is the genuine possibility of not realizing it. Indeed, the freedom of human beings, as contradictory creatures, hinges on the fact that only individuals can resolve this contradiction for themselves. To be free, then, human beings must freely elevate themselves to freedom. As Hirsch puts it, it is incumbent upon me "to make myself into what I only should be from nature, but am not already, to elevate myself to true freedom so that I am not only in my actions, but that all my actions, my whole being, my doing as well as my thinking are solely and exclusively set by me and testify and should testify to nothing but my freedom."26

If no direct relationship with God is possible without undermining the capacity human beings have for freedom, this very capacity for freedom, Hirsch suggests, nevertheless provides an opportunity for an indirect relationship with God. Thus, when human beings grasp their own capacity for freedom negatively, "that there is simply nothing which can compel human being[s] to do something that they have not given themselves, ${ }^{27}$ certain conceptions of God are ruled out. It would be a violation of this strict conception of freedom if God were to intervene in the world of human affairs, to aid or compel the human being towards spirit, as freedom is only free if it is freely chosen by the human being. Yet, this capacity for freedom also points beyond itself to God. Human beings, according to Hirsch, realize that this freedom which they have the capacity to realize can only have been given by "the Almighty, which has absolute power over everything."." Hirsch refers to this knowledge of God as the author of human freedom as the

26. Ibid., 13, "Dieses nun, mich zu dem zu machen, was ich von Natur nur sein soll, nicht aber schon bin, mich zur wahren Freiheit zu erheben, so dass ich nicht nur bei meinen Handlungen bin, sondern dass alle meine Handlungen, mein ganzes Sein, mein Thun sowohl als mein Denken einzig und allein von mir gesetzt werden und nichts Anderes bezeugen und bezeugen sollen als meine Freiheit." Italics in the original.

27. Ibid., 30, "dass es schlechterdings nichts giebt, was den Menschen zu irgend etwas zwingen könnte, hat er sich nicht selbst gegeben."

28. Ibid., 30, "das Allmächtige, das schlechterdings Macht über Alles habende sein.” Italics in the original. 


\section{Robert Erlewine}

"first, most abstract concept of God." ${ }^{29}$ However, given the constraints of freedom - that freedom can only cause and choose itself and that one cannot be compelled into freedom by anything external-Hirsch insists that "free human beings do not enter into a relationship with God, but rather only to themselves.",30

In the first chapter of Die Religionsphilosophie der Juden, Hirsch insists that there is no tension between divine and human agency, because God's agency only functions with regard to the creation of human beings as free beings, such that God's agency does not impinge upon the human being in the course of one's life. Where Kant insists that God must remain a practical postulate of reason that cannot be known with certainty but can only function productively as an object of (reasonable) hope, Hirsh thinks human beings, at least those who eschew idolatry and embrace true religion, attain a secure knowledge of God. Yet this genuine knowledge of God emerges only by means of contemplating their capacity for freedom, a capacity incompatible with any conception of an interventionist God. Thus, precisely because freedom is understood to be a gift from God, the development and realization of freedom is a task that falls to human beings and can only be realized in the purely human sphere. God, as creator of human beings as free, necessarily remains distant, a figure of emulation but not something to be encountered or related to directly.

Hirsch explicitly denies the possibility of a direct relationship with God on the basis of three reasons. First, the language of relationship is bound up with finitude, enmeshed in the concepts of space and time, such that one term borders on and butts up against another. ${ }^{31}$ However, God is infinite and thus cannot be characterized in spatial or temporal terms. Second, the term "relationship" implies mutual dependency. Thus, we talk of the relationship between a child and a parent. Each term or participant in the relationship needs the other: the parent needs the child in order to be a parent just as the child requires a parent to be a child. This cannot apply to God, however, because while human beings stand in need of God, God has no dependency on human beings. And finally, the term "relationship" cannot be straightforwardly applied to God because God is to be understood in immanent terms. "Relationship" implies boundaries or limits. "Human beings also cannot in this sense stand in relation to God, for where human beings are there God is also. For God there is no border." 32 To the degree human beings freely actualize freedom, then, they are "part of the divine life, as bound up and sublated in it." Human beings here "live in a true unity with God." 33

29. Ibid., "Dieses ist der erste abstrakteste Gottesbegriff."

30. Ibid., "Der freie Mensch tritt aber damit nicht in ein Verhältniss zu Gott, sondern nur zu sich selbst."

31. Indeed, Hirsch's language here is striking as the words he uses are prepositions such as vor, nach, unter, zu, auf, über, and thus it would seem that such a notion of relationship as spatial is embedded in grammar itself. See Die Religionsphilosophie der Juden, 25.

32. Ibid., 25-26, "Der Mensch kann daher auch nicht in diesem Sinne in einem Verhältniss zu Gott stehen, denn wo der Mensch ist, da ist auch Gott. Für Gott giebt es keine Grenze."

33. Ibid., 48, "Er lebt in der wahren Einheit mit Gott." Italics in the original. 
This lived unity, however, is to be understood on the purely human level, in terms of behavior and character, not in terms of anything metaphysical. As free, human beings understand not only that God is radically free from and lord over nature but also that God has created human beings for freedom. As such, God "has given to human beings the possibility to elevate themselves to divine freedom. ${ }^{34}$ In their capacity to live freely, to avoid sin and to rule nature, human beings are then "truly in the image of God, like God, essentially related to him, worthy of being called gods." 35

However, this capacity to live in unity with the divine does not diminish the radical distinction between the divine and the human. This unity is not absolute but conditional. Or, as Hirsch puts it, human beings "also know the divine life is absolutely independent from their own." ${ }^{36}$ That is, to the degree that human beings sin, then, they oppose God, fall away from God. In sin, however, human beings have not harmed God but only themselves. God, in God's transcendence, remains unaffected by the choices human beings make. Rather, the distortion or damage of sin pertains not to God but to spirit, understood as a purely human domain riven in two between true and false religion. The relationship with God, again, does not resemble relationships between finite things where one term affects and limits the other but remains indirect. Indeed, Hirsch's claim about the possibility of living in unity with God pertains to the character of human action and not to any sort of felt or experienced harmony with a divine presence.

Hirsch typologically configures the possibility of human beings for comporting themselves towards God in freedom or falling away from God in sin in terms of Judaism on the one hand and paganism on the other. Where Judaism testifies to the capacity of human beings to be free, the religions of paganism - to whose dialectical development he devotes hundreds of pages in the second chapter of Die Religionsphilosophie der Juden - share a conviction that sin is inevitable for finite, corporeal human beings. If this does not immediately seem parallel, freedom here entails the possibility of not sinning, that sin is not an inevitability. Thus, freedom is more than having choice, it is the capacity to act blamelessly. In Hirsch's mind, paganism is an abdication of moral responsibility. "I must sin, so I transfer the guilt of my sin onto another being. This is the absolute Lord, who I am not able to resist." ${ }^{37}$ Paganism, for Hirsch, is characterized by the view that human beings, insofar as they are corporeal, are unable to escape sin. In short, it denies the spiritual or free dimension of human beings, recognizing only the natural. As such, it constitutes a "self-incurred, arbitrary fall of spirit from itself,

34. Ibid., "dem Menschen hat er die Möglichkeit geschenkt, sich zu dieser göttlichen Freiheit zu erheben."

35. Ibid., 455, "Wahrhlich wir sind dann Gottes Ebenbilder, Gott gleich, wesensverwandt mit ihm, werth Götter genannt zu werden."

36. Ibid., 49, "Aber er weiss auch das göttliche Leben schlechterdings unabhängig von dem seinigen." Italics in the original.

37. Ibid., 98, "Ich musste sündigen, so verlege ich die Schuld meiner Sünde in ein anderes Wesen. Dieses ist der absolute Herr, dem ich nicht zu widerstehen vermag. Dieses andere Wesen hat Gefallen an der Sünde und nichts vermag ihm zu widerstehen." Italics in the original. 


\section{Robert Erlewine}

as the self-conscious hostility of spirit against itself." 38 Paganism represents a radical break in spirit itself, such that there is a split between "true and false religion" where false religion consists in "spirit not wanting to be itself." 39 Ultimately, then, whether human beings live in accordance or at odds with God ultimately depends on themselves alone. God's status does not change. God remains distant. Whether or not God is emulated is entirely up to human beings.

If Hegel seeks to grasp religion in terms of a single continuum, whose course of development spans from fetishism to Protestant Christianity, in his first attempt to articulate the relationship of God and human beings, Hirsch presents religion in terms of the dichotomy between Judaism, the true religion, and paganism, which consists of all the others (with Christianity as an intermediary between Judaism and the religions of paganism). Religion is not understood in terms of a developmental process, where the distinction between God and human beings is progressively sublated. Rather, religion is a category divided in two, split between Judaism, which emphasizes human autonomy, and paganism, which denies human freedom and believes sin to be inevitable. ${ }^{40}$ Judaism understands God to be radically transcendent, the emblem of freedom who created human beings with the capacity to be free. However, human beings can only realize their freedom if God remains radically transcendent. In this first answer, then, Hirsch's formulation is distinctly Kantian.

\section{Strategy 2: Freedom and Revelation}

One of the lasting merits of Fackenheim's essay, "Samuel Hirsch and Hegel," is that it discloses the tension that renders Hirsch's ultimate position in Die Religionsphilosophie der Juden incoherent. In the first chapter, as we just saw, Hirsch emphasizes God's radical transcendence to such a degree that the very category of religion is to be understood in purely human terms. And yet, as Fackenheim rightly points out, in his account of Jewish history, developed in subsequent chapters of the book, Hirsch has recourse to an active conception of God who frequently intervenes in history through revelation to prevent the Jews from lapsing into paganism. Thus, where Hirsch in chapter 1 of Die Religionsphilosophie der Juden presents God as radically transcendent, as distant, in chapter 3 he affirms a notion of divine revelation.

In the second argumentative strategy developed by Hirsch, God is now presented in terms of historical agency. To be sure, this sense of divine intervention is presented in rather minimal terms. Hirsch clearly seeks to articulate a conception of revelation that is to be understood as compatible with, and accommodating to, human freedom. Now, God's agency intersects with human freedom, but in such a

38. Ibid., xxvi, "Da aber das Heidenthum sich nicht als vom Geiste gesetzt, sondern als der selbstverschuldete, willkührliche Abfall des Geistes von sich selbst, als die selbstbewusste Feindschaft des Geistes gegen sich selbst zeigen wird."

39. Ibid., xxix, "dass der Geist nicht Geist sein will." Italics in the original.

40. For a discussion of Hirsch's account of religion vis-à-vis Hegel, see Erlewine, "Samuel Hirsch, Hegel, and the Legacy of Ethical Monotheism." 
way, Hirsch insists, that the latter has priority and preserves its integrity. In this second strategy, Hirsch emphasizes the priority of freedom over the content of revelation in two ways: first, revelation is not, strictly speaking, necessary for human flourishing, and second, the human being is the ultimate arbiter and interpreter of this revelation.

As if aware that he has transgressed the Kantian position in chapter 1, in this second strategy Hirsch's position evinces a certain ambivalence towards revelation. He seeks to protect human freedom here, not, as in the first chapter, by conceiving God in radically transcendent terms, but rather by insisting that divine intervention is not actually necessary for human beings to live properly. That is, human beings, as free, possess the capacity to choose correctly for themselves, and are able to reject sin on their own. Thus, while this strategy provides an account of God interceding in the affairs of the world, it also maintains that human beings should not need this assistance. Hirsch insists that even in a world mired in paganism, "every man can have the truth without lies, can live in the truth and does not need to remain dwelling with lies."41

And yet, where Hirsch previously insisted on the capacity of all human beings for freedom, to live in accordance with freedom, he now nevertheless insists that despite this capacity, human beings remain mired in sin and error. This is because as "the consequence of our sinfulness" 42 we indulge prejudices that play on our desires. We do not want the truth. Thus, while human beings are technically capable of seeing the truth even if they live surrounded by lies, "no man, no people, no age has the truth without errors" 43 but rather "the whole unclouded truth is the possession of God." 44

Thus, even if human beings are technically capable of living rightly without revelation, given the actual, contingent history of human beings, revelation is nevertheless indispensable, as without it no one would have had any idea that a true life with God was possible. Thus, the conception of paganism that Hirsch developed in the first two chapters, which is predicated on the conviction that sin is inevitable, continues to be employed. Even if paganism is not inevitable, Hirsch maintains that it is nevertheless the condition in which humanity-at least up to the time of Abraham-finds itself. Thus, while Hirsch contends that human beings should be able to live rightly without miracles, should be able to grasp the truth of their condition without any external help, he simultaneously insists that miracles are needed to break the grip of paganism. Revelation gives the lie to the claim of paganism that $\sin$ is inevitable, and thus creates an opening where human beings might make use of their freedom. Or, as he puts it, "without experience that contradicts the presupposed fundamental idea that man

41. Hirsch, Die Religionsphilosophie der Juden, 453, “aber jeder Mensch kann die Warhheit ohne Lüge haben, kann in der Wahrheit leben und braucht die Lüge nicht bei sich herbergen zu lassen." Italics in the original.

42. Ibid., 452, "die Folge unserer Sündhaftigkeit." Italics in the original.

43. Ibid., "Kein Mensch, kein Volk, kein Zeitalter hat die Wahrheit ohne Irrthum."

44. Ibid., "die ganze ungetrübte Wahrheit ist nur das Eigenthum Gottes." 


\section{Robert Erlewine}

must sin, that Natürlichkeit and nature are the highest, neither the individual nor a whole people comes out of paganism." 45

If the second approach to conceptualizing God requires some recourse to divine intervention, it nevertheless continues to maintain the inviolability of human freedom. Since human freedom must, qua freedom, actualize itself, it cannot be compelled from the outside. Since Hirsch claims that God desires to cultivate human freedom, this strategy maintains that miracles and revelation cannot automatically institute desired changes in behavior, or else they would undermine human freedom rather than further it. Freedom can only ever be chosen and actualized by human beings themselves. Thus, when God does intervene in human affairs, this intervention cannot be the ultimate factor in whether or not human beings embrace their capacity for freedom.

Hirsch evinces this concern with protecting the integrity of freedom in his account of miracles. "They are happenings and want to signify something, however, human beings must search for the key to this meaning in themselves." 46 Even when confronted by wonders, human beings can take on an attitude of "defiance" and dismiss all miracles as meaningless accidents or as only relevant for "temporal goals." 47 It is up to human beings themselves to properly recognize these miraculous events for what they are. In order to make them speak clearly, the hard work of spirit is required. Miracles alone are insufficient "to liberate" either an individual or a people "from the opprobrium of paganism." though God intervenes in the world, the freedom of human beings cannot be violated, it must be respected. As a result, few human beings ever properly grasp the true significance of miracles. ${ }^{49}$

For a miracle to be effective, then, it is not enough to come from God. The miracle must be accompanied by the presence of "the inner voice of the pure heart, the sincere search for truth." 50 This capacity to scrutinize one's own judgment, however, falls within the terrain of freedom, and is thus not something that can be directly influenced by God. God can intervene, but unless human beings are there to respond authentically, this interaction will fall on deaf ears and blind eyes.

To be sure, the first two argumentative strategies that Hirsch develops for understanding the human being and God are quite close at points. While the characterizations of revelation as not necessary and as ambiguous could be compatible

45. Ibid., 595, “ohne Erfahrungen, die dem vorausgesetzen Grundgedanken, dass der Mensch sündigen müsse, dass die Natürlichkeit und die Natur das Höchste wären, geradezu widersprechen, kommt weder der Einzelne noch ein ganzes Volk aus dem Heidenthum heraus." Italics in the original.

46. Ibid., 451, "Sie sind geschehen und wollen etwas bedeuten, aber den Schlüssel zu dieser Bedeutung muss der Mensch in sich suchen." Italics in the original.

47. Ibid., 595.

48. Ibid., "von der Schmach des Heidenthums."

49. Ibid., 451.

50. Ibid., 595, "die innere Stimme des reinen Herzens, das aufrichtige Suchen nach Wahrheit." Italics in the original. Of course, Hirsch is on less solid ground when he adds that this pure heart and upright search for truth are to be characterized as "instructing man that it is thoughtless to speak of accident" (den Menschen belehrt, dass von Zufall zu reden gedankenlos ist), since this would seem to remove any sense of contingency and render revelation necessary. 
with the account of freedom discussed in the first chapter of Die Religionsphilosophie der Juden, they are not compatible, as Fackenheim has pointed out, with the denial of the possibility of a divine-human relationship that he builds as a corollary to this account of freedom. ${ }^{51}$ Thus, we must treat this answer as discrete from the first. The first solution answers the question about the compatibility of divine and human agency by assigning them to different spheres. Where human agency is entirely focused around self-fashioning, divine agency is configured in terms of the creation of human beings as free. Not only does Hirsch seek to understand the concept of religion on this basis, he also roots his account of religious difference, that between true and false religion, in it as well. In the second answer, however, Hirsch presents God as intervening, sending messages, to provide human beings the opportunity to recognize their capacity for freedom, since the world itself is overrun by idolatry, by the very denial of this capacity for freedom.

And yet, Hirsch proceeds not only to elaborate an account of divine intervention but to make it central to his Heilsgeschichte, which is formulated along the lines of the opposition between true and false religion. While human beings are free, and thus have the capacity to avoid sin and to live in unity with the divine, they do not actually do so. The world is mired in sin and human beings consistently choose to become slaves of nature rather than live in unity with God. To address this situation, then, Hirsch has recourse to a God who intercedes in history to bring human beings back from sin and to at least give them the opportunity to embrace freedom. Where the first strategy insists on God's distance, the second one now depicts God as mercifully inclined toward human beings, as not only desiring to free them from sin but also actively taking measures to rehabilitate them so that they can properly actualize freedom. It is as a result of this interventionist dimension of God that Hirsch contends that human beings are to be understood in an exalted sense, as God's "children and not simply his creations, he is our father and educator and teacher and not simply our creator." 52

Hirsch's second strategy for reconciling divine agency and human freedom is developed in the course of his lengthy exegesis on the Abraham stories in Genesis. Abraham represents an exemplary figure, who refutes paganism and affirms the true order of the world. "Every human being who seeks God, finds him because in the destiny of each, God speaks clearly enough for those who sincerely strive for truth. ${ }^{53}$ The truth that Abraham finds is that "human beings are free, that God continually educates them to freedom, and that they should educate

51. Indeed, as Fackenheim above all has suggested, the first answer, particularly if it is to function as a response to Hegel, cannot countenance any sense of intervention by the divine; "Samuel Hirsch and Hegel," esp. 29-30 and 35-37.

52. Hirsch, Die Religionsphilosophie der Juden, 455-56, "Wir sind alsdann siene Kinder und nicht blos sein Geschöpfe, da er unser Vater und Erzieher und Lehrer und nicht blos unser Schöpfer ist." Italics in the original.

53. Ibid., 457, “Jeder Mensch, der Gott sucht, findet ihn weil in dem Schicksal eines Jeden Gott für den aufrichtig nach der Wahrheit Strebenden deutlich genug redet." Italics in the original. 


\section{Robert Erlewine}

themselves, indeed, without interruption. ${ }^{, 54}$ While God intervened in and shaped the course of his life, what proves to be decisive is Abraham's own upright search for truth in discerning this involvement. "He in fact considers that God brings about every experience in order that he can be even more cultivated in freedom. ${ }^{\circ 5}$ Thus, the fact that God went unrecognized among the pagans, "does not prove that man can only come to God through a supernatural way." Rather, the fault for not finding God lies squarely with the pagans who privileged happiness over freedom. Hirsch insists that God can be found by anyone who earnestly searches for God. Abraham's example proves this. What Abraham accomplishes, Hirsch contends, everyone could. Indeed, Abraham is exemplary precisely because he is ordinary - or at least should be - in that every human being could, at least theoretically, live as fully in accord with freedom as he does. The truth that drives Abraham, Hirsch insists, "is so clearly written in the breast of everyone ... that no extraordinary revelation is required for them to come to it." ${ }^{, 57}$

And yet, while Hirsch's account of Abraham is quite rationalist in coloring, it nevertheless insists on the role of divine intervention in the course of Abraham's life. Hirsch maintains that because Abraham lived in a world mired in paganism, his conscience could not have developed in a manner sufficient for morality. As Hirsch explains, "But in the time of Abraham the world was completely alienated from this content [i.e., the moral content proclaimed in revelation], and the mere voice of his conscience could not lead him to the truth." ${ }^{58}$ Thus, on the one hand, Abraham achieves universal significance, exemplifying the good life such that all other human beings could follow his example without any supernatural revelation. And yet, on the other, achieving this actually requires revelation. God had to directly intervene into the realm of human action and make himself present to Abraham. ${ }^{59}$ One sympathizes with Max Wiener, who expresses consternation with this aspect of Hirsch's thought, describing this account of revelation as "superfluous." ${ }^{60}$ And yet, Wiener's claim that this move is merely an "accommodation to the traditional standpoint" does not hold, ${ }^{61}$ because in Hirsch's third

54. Ibid., "dass der Mensch frei ist, dass Gott ihn fortwährend zur Frieheit erziehet und dass er sich selbst ebenso ohne Unterbrechung zur Freiheit erziehen soll."

55. Ibid., 471, "Jede Erfarhung sieht er vielmehr als von Gott herbeigeführt an, um ihn noch mehr in der Freiheit zu üben."

56. Ibid., 458, "so beweist dieses durchaus nicht, dass nur auf übernatürliche Weise der Mensch zu Gott kommen kann."

57. Ibid., 457-58, "ist so deutlich in eines Jeden Brust geschrieben ... dass zu ihr zu kommen, es keiner ausserordentlichen Offenbarung bedarf." Italics in the original.

58. Ibid., 480, "aber zur Zeit Abrahams war die Welt diesem Inhalt völlig entfremdet, die blosse Stimme seines Gewissens hätte ihn daher auch nicht zur Wahrheit führen können.”

59. I am deliberately using the male pronoun for God not merely to accord with Hirsch's usage, but to help illuminate the conceptual distance between the abstractness of the account of God in the first answer and the more anthropomorphic character of God in this second answer (and which will continue to apply to the third solution as well).

60. Wiener, Jüdische Religion im Zeitalter der Emanzipation, 136.

61. Ibid., 137, "eine Akkomodation an den Ueberlieferungsstandpunkt." 
solution to the question of how to balance divine and human agency (which will be discussed shortly) God's interventionist tendencies are only amplified. In the end, then, Hirsch's claim that "we see in Abraham the development of the religious life on the whole, the development of the purely human and its actualization" cannot be taken in any straightforward sense. ${ }^{62}$ Abraham, for Hirsch, exemplifies the concrete actualization of freedom, and yet, this actualization would have been impossible without divine revelation. Even if we insist that Abraham freely chose to recognize that this revelation in fact came from God and for the purpose of educating him to freedom, the clear distinction between divine and human agency developed in the first chapter has now been substantially muddied. Indeed, if the first chapter presented God as so distant as to be impersonal, available for emulation by human beings, but ultimately indifferent and unaffected by their failures, with the second strategy developed in chapter 3, God is now presented as concerned about their spiritual well-being. God reaches out to and solicits the attention of human beings, seeking to guide them to the path of righteousness. This God is no longer to be understood as merely an object of emulation, but now as a subject who entreats and appeals to human beings.

\section{Strategy 3: The Priority of God's Agency}

Up to now, we have explored two different strategies that Hirsch has employed for articulating the relationship between God and human beings, namely, an emphasis on a distant God who makes room for human freedom, and an interventionist God who entreats human beings to use their capacity for freedom, albeit in a manner that seeks to preserve this very capacity. In chapter 4 of Die Religionsphilosophie der Juden Hirsch now develops a third approach to the relationship of human and divine agency. This chapter traces the history of the Jewish people as pursuing an education to freedom in a manner that replicates Abraham's course of life, albeit on a collective level. ${ }^{63}$ Like the patriarch, the Jewish people bear witness to God and to God's desire for human beings to actualize their capacity for freedom in their lives. Hirsch claims that "only when an entire people had acquired their freedom could the other peoples also experience the truth and excellency of freedom.." ${ }^{, 64}$ The third answer takes shape in regard to

62. Hirsch, Die Religionsphilosophie der Juden, 470, "so sehen wir in Abraham die Entwickelung des religiösen Lebens überhaupt, die Entwickelung des Reinmenschlichen und seine Verwirklichung." Italics in the original.

63. Abraham's life embodies both what Hirsch terms extensive and intensive religiosity, in that he lived as a wandering preacher sharing the truth about the human condition wherever he traveled on the one hand, and that he transforms his very life into an embodiment of this truth as a form of testimony on the other. Hirsch subsequently develops a systematic account of Christianity and Judaism in terms of the dialectical tension of these different aspects of Abraham's life and religiosity. While this dimension of Hirsch's thought merits further study, it is beyond the scope of the present essay.

64. Hirsch, Die Religionsphilosophie der Juden, 556, "denn nur wenn ein ganzes Volk sich die Freiheit angeeignet hatte, konnten auch die übrigen Völker die Wahrheit und Trefflichkeit der Freiheit erfahren." Italics in the original. 


\section{Robert Erlewine}

this transformation of Abraham's endeavor from the individual to the collective level. In one sense, the manner in which Hirsch seeks to reconcile human freedom with divine agency here is the most undeveloped and least tenable of all of the attempted solutions that he provides in Die Religionsphilosophie der Juden. And yet, on the other hand, this answer is perhaps most intriguing precisely because it so clearly reveals the tension that will lead to the development of two mutually exclusive schools of thought within Jewish philosophy in the twentieth century.

While the first two answers marshalled by Hirsch are distinct, they are both characterized by an emphasis on human freedom. The first answer maintains that God can only be approached indirectly, by the human being actively choosing to realize the potentiality for freedom and thereby emulating God. The second maintains that while there may be incursions into the human realm by God, these interventions are marked by ambiguity, such that human freedom is always preserved. The first answer rejects the possibility of a divine-human relationship, maintaining that one either lives in accordance with God or falls away from God on the basis of one's own actions. In contrast, the second presents God as genuinely concerned with the inevitable - although not logically necessary - fall of the human being into sin, seeking to call the human being back to freedom. God's revelatory intervention is necessary, but only in ways that preserve human freedom and only for the purpose of furthering its development. Where the first two answers, albeit in different ways and to different degrees, prioritize human agency, the third subordinates it to that of the divine. Here it is God who not only elects the Jews to be his servants but who compels them, sometimes against their will, to bear witness to him.

In chapter 4 of Die Religionsphilosophie der Juden, God's agency is central to the history of the Jewish people, such that in their history God makes his presence known "as nowhere else," revealing himself as "the holy and the one who makes holy, as the father and educator who is ever among his children." 65 Or, put another way, "The revelation of God in Israel is precisely the history of Israel." ${ }^{66}$ However, there is an ambiguity in such claims insofar as Hirsch follows Gotthold Lessing in describing revelation as an education to freedom, ${ }^{67}$ apparently in an effort to preserve the integrity of human freedom. ${ }^{68}$ This might

65. Ibid., 619, "denn bis dahin zeigte sich Gott in Iisrael, wie nirgends anders, als der Heilig und heilig Machende, als der Vater und Erzieher, der immer unter seinen Kindern ist." Italics in the original.

66. Ibid., "Die Offenbarung Gottes in Iisrael ist eben die Geschichte Iisraels." Italics in the original. Guttmann, Philosophies of Judaism, 318, points out that Hirsch treats Jewish history, which testifies to their unlikely survival, as itself a miracle, indeed, the only one in the modern world.

67. Of course, there is the question of how to properly interpret Lessing, a thinker whose work is replete with esoteric meanings. For a careful consideration of Lessing's "Education of the Human Race," which takes these concerns seriously, see Toshimasa Yasukata, Lessing's Philosophy of Religion and the German Enlightenment (Oxford: Oxford University Press, 2002), 89-116.

68. Fackenheim, "Samuel Hirsch and Hegel," 36, notes that this attempt to cast revelation in terms of an education to freedom remains "a fatal contradiction" to which Hirsch "is curiously oblivious." That is, even if one characterizes God's revelation in terms of an education that is intended to 
lead one to interpret Hirsch's account of Jewish history, and God's presence in it, in terms of the first two answers he has already provided. Indeed, Hirsch continues to make the language of human freedom central, and, as we will see, the first two strategies are not entirely abandoned but continue alongside the third, despite their incongruence. Indeed, the third strategy can be seen to waver at moments in terms of its starkness, often juxtaposing a rarified rationalism with a blunt anthropocentrism, with sometimes bizarre results.

Like Abraham before them, the Jewish people are distinguished precisely by their exemplarity. That is, their particularity consists paradoxically in their universality, in that they embody the model that everyone else should - and yet do notalso follow. Thus, if they maintain a special relationship with God, if they are elected by God to bear witness to the possibility of a life of actualized freedom, this distinction itself should fall away as all other peoples realize that they too should be acting to realize freedom in their lives, a move that would eliminate their essential difference from the Jews. ${ }^{69}$ Thus, in keeping with the second strategy, God directly intervenes in the form of signals that are sufficiently ambiguous to protect the integrity of freedom while nevertheless able to be read and properly interpreted by those of good moral character. This is sufficient to enable God to break the grip of paganism by enabling the Jews to preserve their own freedom. And in keeping with the first strategy, then, insofar as Jews realize freedom, insofar as their lives embody the imitation of God, then they live in unity with God. Thus, it might seem that Hirsch's account of the Jews has not engendered a third answer to the question of how to square human freedom and divine agency, but rather that it remains within the ambit of the first two, which are themselves quite close.

However, Hirsch proceeds to depict God as compelling the Jews to serve as his witnesses and as messengers bringing forth his intentions to humanity at large in a manner at odds with the first two strategies. The result of this claim is quite ironic, in that the Jews are compelled through force or threat of force into being witnesses to humanity's capacity for living a life characterized by freedom. When arguing that God compels the Israelites to serve as his sign to the nations, that God punishes and rewards as a means of preventing them from backsliding into paganism, Hirsch no longer privileges human freedom. In the first attempt to square human agency with the divine, Hirsch defines human freedom in terms so stark that it requires as its precondition that God's agency never intersect with the historical world of concretely existing human beings. In the second answer, God intervenes by sending messages and signs into the human world, but because human beings are free, the recognition and appreciation of these signs is by no means a foregone conclusion. This account, while less emphatic in distinguishing the human realm from the divine, nevertheless continues to grant a

foster autonomy in its recipients, it still intereferes with human freedom at least as it is defined with regard to what I have elaborated as Hirsch's first (and possibly second) answer.

69. Indeed, Hirsch thinks that in the messianic age, the only distinct feature of the Jews will be how they worship, and that they will receive their own temple in Jerusalem. 


\section{Robert Erlewine}

significant role to human freedom. Indeed, the difference between true and false religion still depends entirely on human responsibility. But now, in this third answer, Hirsch casts God's interventions in decisive, unambiguous terms with regard to his relationship with the Jewish people.

If Hirsch once attended to Kant's worry that certain conceptions of God are incompatible with autonomy and thus undermine the very possibility of morality, in this third account of the relationship between God and human beings, he shows no such concerns. Here, God, whose agency is now undeniable, compels human beings to serve the specific historical end of bearing witness to the universal human vocation of realizing their capacity for freedom. Hirsch's desire to preserve the emphasis on human freedom accords badly with the growing prominence given to God's agency. Indeed, Hirsch increasingly insists that the Jewish vocation to bear witness to freedom is not itself freely accepted or willed by the Jews. Rather, as he goes on to insist, it is thrust upon them by God, who compels them to act as witnesses. Thus, he explains, "No one, who was born a Jew, can escape the divine calling of his people." "I0 Indeed, God, who intends human beings for freedom, serves as an educator "in whose hand every means of correction is found." ${ }^{, 71}$ The purpose of punishment, of course, is correction or instruction, to "make sinners conscious of what actual sin, in fact, is, namely: the contradiction in itself, the contradiction of human beings against their own essence." thus, Hirsch suggests that divine punishment stems from the same love for human beings that led to God intervening through miracle and revelation in the second strategy.

Of course, the claim that God punishes sin does not necessarily run afoul of the balance between human freedom and divine intervention that Hirsch established in the second strategy. Indeed, with regard to paganism, Hirsch preserves the integrity of human freedom. ${ }^{73}$ While Hirsch suggests that sin corrodes human freedom, he also maintains that evil can only be obliterated through the efforts of human beings themselves. As Hirsch puts it, "Evil is nothing external to human beings, but rather only the misuse of their freedom; it can therefore only be annihilated through the human being's own free deeds." ${ }^{74}$ However, for human beings mired in paganism to choose their freedom, they must grasp that evil is nothingness, that sin is vanity. Indeed, this is precisely what Hirsch

70. Hirsch, Die Religionsphilosophie der Juden, 865, "keiner, der als Jude geboren ist, kann sich dem göttlichen Berufe seines Volkes entziehen." Italics in original.

71. Ibid., 455, "Einen Erzieher giebt es daher, in dessen Hand jene Zuchtmittel sich befinden."

72. Ibid., 49, "Diese bringt es dem Sünder zum Bewusstsein, was die wirkliche Sünde in der That ist, nämlich: der Widerspruch in sich selber, der Widerspruch des Menschen gegen seine eigenes Wesen." Italics in the original. Note this passage is from the first chapter that is otherwise to be distinguished for its emphasis on what I have characterized as the first answer.

73. On the challenges Hirsch's notion of freedom poses for his attempts to use the dialectical method, see Guttmann, Philosophies of Judaism, 318, and Fackenheim, "Samuel Hirsch and Hegel," 33-34.

74. Hirsch, Die Religionsphilosophie der Juden, 666-67, "allein das Böse ist nichts dem Menschen Aeusserliches, sondern nur der Missbrauch seiner Freiheit; es kann daher auch nur von der eigenen Freihätigkeit des Menschen, vernichtet werden." Italics in the original. 
thinks happens when the dialectic of the pagan religions reaches its culmination and collapses. To be sure, the earnest searcher for truth could reach this conclusion on his or her own. Yet, while such a conclusion is possible for the individual to realize on her or his own, for humanity to realize it paganism has to collapse upon itself, a process Hirsch lays out in his development of the dialectic of paganism in the second chapter of Die Religionsphilosophie der Juden. In this process, God remains at a distance, allowing the dialectic to run its course and thus sin to collapse under its own weight. God can be seen to be an educator in this process insofar as paganism's self-unfolding dialectic eventually reveals the emptiness of sin to the (former) adherent of paganism. To the extent that sin is empty, it is not ultimate and "cannot truly contradict God." ${ }^{75}$ When—or if-human beings who have succumbed to paganism recognize their capacity for freedom, God will receive them back again. In other words, the human being can, after sin, freely reject this way of life and resume the upright life of freedom, thus living an existence in harmony with God. This account of divine punishment more or less accords with the emphasis on human freedom in the first two strategies.

Yet, in articulating his account of Jewish history, Hirsch is unwilling to settle for a depiction of the Jews as suffering in order to bear witness to the one true God, with being "abstract missionaries of an Idea." ${ }^{.76}$ Rather, this history is presented in terms of a direct relationship with God. Hirsch's insistence on God's direct intervention overwhelms any precautions previously put in place to preserve the integrity of the capacity of human beings for freedom. Indeed, Hirsch's ambivalence on this front is on display in passages such as the following:

God never wants to compel human beings to virtue, only voluntarily should human beings come to God, realize their freedom. Therefore, God always leaves human beings the possibility to sin, in spite of miracles and prophecy and in spite of the visible appearance of God on Sinai, and unfortunately Israel made good use of this possibility. But God created [the Israelites] that they should live for the truth and not for the lie. Therefore he does not surrender [them to their] falseness, as with the pagan peoples [with regard to] their own self negating dialectic ... from which only nothingness could result, but rather he punishes. ${ }^{77}$

75. Ibid., 840, "vermag aber nicht Gott wahrhaft zu widersprechen."

76. The phrase "abstract missionaries of an Idea," is taken from Fackenheim's brief discussion of Hirsch in his essay "Moses and the Hegelians" in Encounters between Judaism and Modern Philosophy, 128.

77. Hirsch, Die Religionsphilosophie der Juden, 617, "Gott will niemals den Menschen zur Tugend zwingen; nur freiwillig soll der Mensch zu Gott kommen, seine Freiheit verwirklichen. Daher lässt Gott dem Menschen immer die Möglichkeit, trotz Wunder und Prophetie und trotz der sichtbaren Erscheinung Gottes am Sinai, zu sündigen und leider machte Iisrael von dieser Möglichkeit weidlichen Gebrauch. Aber Gott hatte Iisrael geschaffen, dass es für die Wahrheit und durchaus nicht fuer die Lüge leben sollte. Daher überliess er seine Lügenhaftigkeit nicht, wie die der heidnischen Völker der eigenen sich selbst vernichtenden Dialiketik, aus welcher nur das Nichts resultiren konnte ... sondern er strafte." Italics in the original. 


\section{Robert Erlewine}

The first sentence, "God never wants to compel human beings to virtue, only voluntarily should human beings come to God, realize their freedom," fits with the priority accorded to the capacity for freedom in the first two strategies advocated by Hirsch. The human being becomes like God through actualizing freedom. And since freedom can only be an activity of the self, the self cannot be compelled by anything external to it—even God - to actualize its capacity for freedom. Thus, "miracles and prophecy" and indeed, even the "visible appearance of God at Sinai," ${ }^{78}$ do not overpower the freedom of human beings. "God always leaves man the possibility ... to sin, and unfortunately Israel made good use of this possibility." Thus, the first two sentences of the passage quoted above are in keeping with the second strategy by maintaining that human freedom, even in the wake of Sinai and the prophetic tradition, is decisive with regard to divine revelation. God cannot force someone to be free. Yet, Hirsch does not leave his statement there. He proceeds, "But God created [the Israelites] for the truth and that they should not live for the lie. Therefore he does not surrender [them to their] falseness, as with the pagan peoples." If God allows the pagan dialectic to play out, does not interfere in order to preserve the integrity of human freedom, this attitude fundamentally changes with regard to the Jews.

Hirsch presents God as providing incentives, rewards and punishments, to guide the Jews to embody freedom. The Jews either "grasp their vocation with fidelity and warmth" 79 or they "continue to forget their God, to prefer the pleasure of the flesh and the worship of nature to the freedom of God." ${ }^{\circ 0}$ If the former, then they dwell happily "under the protection of divine light," ${ }^{81}$ but if the latter, "God will scatter Israel among the peoples" to dwell in suffering and shame until "they will return to the Lord and listen to His voice, and the Lord will accept it again.." 82 Indeed, this divine intervention seems to be required here both because without it the Jews would fall into the contradiction of paganism like everyone else, ${ }^{83}$ and because this combination of punishment and preservation, of disaster coupled with survival, is precisely how their status as elect is demonstrated to the nations. Yet, if the peoples of the world are free to recognize or harden themselves against the miracle of Jewish existence, Hirsch's account of the experience of the Jews lacks this same consideration for human agency. Indeed, as Hirsch himself puts it, for the Jewish people, "their history must teach that if they do not voluntarily fulfill their Israelite calling, God compels them to do so." ${ }^{\text {84 }}$ By making God

78. Elsewhere Hirsch notes that God cannot be visible because God is not a being of nature.

79. Hirsch, Die Religionsphilosophie der Juden, 627, "erfasst mit Treue und mit Wärme seinen Beruf."

80. Ibid., 627, "fortfährt seines Gottes zu vergessen, sich den Lüsten des Fleisches hinzugeben und die Sklaverei der Naturverehrung der Freiheit in Gott vorziehen."

81. Ibid., "unter dem Schutze des göttlichen Lichtes."

82. Ibid., 628, "Gott wird lisrael zerstreuen unter die Völker ... wird es zum Herrn zurückkehren und auf seine Stimme horchen und der Herr wird es wieder annehmen."

83. See Fackenheim's discussion of this point in "Samuel Hirsch and Hegel," 34.

84. Hirsch, Die Religionsphilosophie der Juden, 880, "denn seine Geschichte muss es belehren, dass, wenn es nicht freiwillig seinen iisraelitischen Beruf erfüllen will, Gott es dazu zwingt." Italics in the original. 
the instigator of this punishment and suffering, this process of education would seem to compromise rather than cultivate the very freedom that is to be the message of Judaism to the peoples of the world.

If Hirsch's answer in chapter 1 of Die Religionsphilosophie der Juden accorded quite clearly with Kant's worry that knowledge about divine punishment or reward is incompatible with autonomy and thus genuine morality, the third approach to God and human beings directly contradicts it. Indeed, if the Jews testify to God's desire for human beings to be free, it would now appear that they do so by means of a process that involves the destruction of their own freedom. Given the swift certainty of divine punishment and reward in Hirsch's account, it is hard to see how he can now avoid Kant's worry that "God and eternity with their dreadful majesty would lie unceasingly before our eyes," "most lawful actions would be done from fear, only a few from hope, and none at all from duty." $" 86$ It is difficult to see how Hirsch could sustain any notion of human freedom here for the Jews that even approximates autonomy. Everything would be done from reactive or pragmatic reasons, it would seem.

Why does God, previously understood to be radically transcendent and distant in order to preserve the integrity of human freedom, now intervene to blatantly reward and punish the actions of the Jews? The only possible answer is that God needs the Jews to fulfill their mission. That is, a profound shift has taken place within Hirsch's thought that renders it unstable and even incoherent. The bizarre quality of this position surely stems from the fact that in Hirsch's anthropology the essence of the human being is freedom, and that this correlates with a conception of God rooted in radical transcendence. Such a God, if we recall, cannot be said, strictly speaking, to be in relationship with human beings, not only since God is neither spatial nor temporal, but because there can be no mutual dependency between God and human beings. The human being may stand in need of God but God does not require anything of human beings. At least this was Hirsch's position in chapter 1 of Die Religionsphilosophie der Juden. However, gradually, Hirsch's account of religion has shifted. Initially, religion was supposed to be about human beings' relationship with their own capacities for freedom. God is not a partner in this process. To be sure, it is essential that God be understood correctly, as the proper conception of God is a necessary condition for avoiding paganism's poisonous denial of freedom. However, if human beings need the proper conception of God to live correctly, God, nevertheless, remains unaffected by human beings.

This vision of divine and human agency changes fundamentally in the second and third strategies that Hirsch employs. In the second, God intervenes, issues revelatory messages, as a countermeasure to the predominance of sin within human history. To be sure, human beings could in fact live a life without sin, as they genuinely possess the capacity for freedom. However, the world as 


\section{Robert Erlewine}

it actually is makes such a life virtually impossible without divine intervention to offset the insidious influence of paganism. Thus, God is not so indifferent and unaffected by human beings as Hirsch initially maintained, as God finds intervention to be necessary.

That the relationship is no longer merely a one-sided human dependence on God becomes undeniable in the third answer. God punishes and rewards the Israelites precisely because they have a relationship. God requires the Jews to dutifully live up to their covenant relationship with him, to testify about God to the nations of the world. If they will not do this freely, then God compels them. In short, God punishes the Jews because God needs them to fulfill their obligations to him. That God takes recourse to punishment and force here reveals a vulnerability, that God's plans can be thwarted and harmed by the actions of the Jews. That the message that the Jews find themselves compelled to bear witness to is about the capacity for human freedom is rather ironic, but it should not obscure our view of the significance of the conceptual shift that has taken place from a distant, impersonal God to a God that is bound up in a mutual relationship with, and, indeed, who stands in need of the Jews.

And yet, while Fackenheim presents modern philosophy, again filtered through Kant, as incompatible with divine agency, it would be a mistake to conclude that as Hirsch's thought embraces theocentrism it somehow sheds its modern philosophical connections. In this third strategy, Hirsch continues to trade on the education of the human race, the celebration of freedom framed in moral terms, and to cast the election of the Jews in terms of exemplarity. Whether or not this is good philosophy can be argued, but the concepts in play here are undoubtedly modern.

\section{CONCLUSION: HiRsch's CONTRADICTIONS}

In this essay, I have argued that Hirsch's Die Religionsphilosophie der Juden falls into contradiction because it makes use of three different strategies for reconciling its commitments to human freedom and divine agency without sufficiently choosing between them. Thus, I reject Fackenheim's attempt to present the contradictions that beset this text as exemplifying the incompatible assumptions underlying (Kantian) modern philosophy and authentic Jewish theology. Providing a corrective to Fackenheim's reading is important not merely because Die Religionsphilosophie der Juden is an unfairly neglected work that merits more attention than it has received in recent years, but also, and arguably more importantly, because it can help us better understand the contemporary landscape of modern Jewish thought.

Of course, certain facets of the composition history of Die Religionsphilosophie der Juden should be acknowledged, as these can provide some insight as to how these contradictions emerged. Hirsch wrote the chapters of this work individually, sending them off to Leopold Zunz for publication one at a time. As a result of this process, when he was composing later chapters, he very well may not have had access to his earlier ones. In an age before digital files, in his mad dash to publish this massive, sprawling text, it is quite conceivable that Hirsch 
simply lost track of the intricacies of his argument. ${ }^{87}$ Another possible explanation for these discrepancies, one quite complementary with the previous one, is that Hirsch develops the argument of Die Religionsphilosophie der Juden in the form of allegorical biblical exegesis. In the first chapter he is dealing with Genesis 3, in the third, with Genesis 12-25, and then in the fourth with passages from a variety of biblical books. Thus, it is quite conceivable, indeed probable, that the divergences in the argument stem, at least in part, from discrepancies between the biblical passages whose very exegesis provides the occasion for Hirsch to articulate his philosophy in the first place.

While such considerations can help explain the origin of these problems in Hirsch's argument, they do not provide any sufficient justification for retrieving this work from the relative oblivion into which it has fallen. Yet, Hirsch's work is relevant to contemporary conversations despite its inner tensions, or perhaps better, because of them. It is striking how the different strategies Hirsch employs to reconcile divine agency and human freedom, particularly the first and third, align with different camps in a dispute central to twentieth-century Jewish thought about precisely this issue.

If Fackenheim claims that "authentic" Jewish theology is incompatible with the Kantian assumptions of modern philosophy, many other Jewish thinkers have long claimed a deep affiliation with Kant's ethical and religious thought. ${ }^{88}$ Indeed, Kant's view that conceiving God in interventionist terms undermines morality finds a welcome home within the ethical monotheist strand of modern Jewish thought. Following Kant's concern, Hermann Cohen and Emmanuel Levinas, for instance, both insist that morality is only possible if God's presence does not permeate the human realm. Thus, in "Religion und Sittlichkeit," Cohen insists that where "myth is spellbound by the relationship between the human being and God," the "prophetic conception of God emerges on the basis of the relationship between human being and human being." That is, in prophetic religiosity, which, for Cohen, is synonomous with Judaism, the "relationship with God" is entirely consequent upon the relationship between human beings. ${ }^{89}$ In genuine religion, which is distinguished from myth as a result of its ethical focus, God is conceived not in terms of power "but rather only as the pattern, the sketch,

87. I am grateful to one of the anonymous reviewers of this essay, who brought this fact, as revealed in the Hirsch-Zunz correspondence (Jewish National and University Manuscript Division), to my attention. For an insightful discussion of Hirsch, which situates Die Religionsphilosophie der Juden amid his other writings of this period, see Gershon Greenberg's forthcoming piece, "Samuel Hirsch in Dessau."

88. A classic example of this can be found in Julius Guttmann, "Kant und das Judentum," in Schriften, herausgegeben der Gesellschaft zur Förderung der Wissenschaft des Juden (Leipzig: Buchandlung Gustav Fock, 1908), 43-59.

89. Hermann Cohen, "Religion und Sittlichkeit," in Hermann Cohens Jüdische Schriften, vol. 3 (New York: Arno, 1980); repr. of Hermann Cohens Jüdische Schriften, ed. Bruno Strauss (Berlin: Akademie für die Wissenschaft des Judentums, 1924), 125. "Der Mythos ist festgebannt auf das Verhältnis zwischen Mensch und Gott; der prophetische Gedanke Gottes ensteht auf Grund des Verhältnisses zwischen Mensch und Mensch. Von dieser Stufenleiter erst erhebt sich die Beziehung auf Gott." Italics in the original. 


\section{Robert Erlewine}

according to which human beings establish their actions." 90 Similarly, Emmanuel Levinas insists that morality, which is considered the basis of true spirituality, is only possible if human beings have the capacity to doubt God's existence and involvement in the world. Indeed, Levinas insists that the "risk of atheism" is not to be understood as antithetical to monotheism but rather is an essential precondition for developing "the spiritual notion of the transcendent." ${ }^{\text {" C1 }}$ Contra Fackenheim, for Cohen and Levinas, Kant's worry that certain conceptions of the divine threaten to erode and undermine human freedom is not only a penetrating insight, but one that is profoundly in accord with the central insights of Jewish spirituality. Both thinkers work to show that "authentic" Jewish theology, that is, Jewish theology when it has not been corrupted by syncretistic accretions, conceives of God in radically transcendant and noninterventionist terms. For these thinkers, then, the emphasis on God's transcendence is not incidentally bound up with the austere and superogatory moralism that they associate with the essence of Judaism, but rather it is inseparable from it.

If thinkers like Cohen and Levinas reject the possibility of any sort of concrete divine-human relationship, Fackenheim is by no means the only prominent voice to insist on the centrality of the direct relationship between the divine and human beings for Jewish theology. For instance, in The Body of Faith: God in the People of Israel, rather than casting divine and human agency as mutually exclusive, Michael Wyschogrod insists that they condition one another. Indeed, for Wyschogrod, God's agency is not antithetical to human freedom but requires the integrity of human freedom for its very exercise. Through recourse to Hegel's master-slave dialectic, Wyschogrod presents the identities of divine and human as mutually dependent, as having their respective agencies intertwined such that each party requires the recognition of the other. Thus, if Kant argues that contact with the divine overpowers and undermines human agency, Wyschogrod insists that God's very "lordship" is predicated on "the ability [of human beings] to disobey or to ignore the divine command." 92 That is, for God to be God, the human being must be "a participant in the [divine-human] relationship who makes his own decisions which can interfere with Hashem's plans." 93 This fraught relationship constitutive of the identities of both God and human beings is presented as a "battle" that cannot ever be "certain" lest "the resulting combat be staged and therefore unreal." $" 94$ It is, then, not only for the sake of the human

90. Ibid.," 135, “Gott bedeutet nicht die Kraft, aus welcher der Mensch seine Sittlichkeit schöpfen kann, sondern lediglich das Musterbild, die Vorzeichnung, nach welcher er seine Handlungen einzurichten hat." Italics in the original.

91. Emmanuel Levinas, "A Religion for Adults," in Difficult Freedom: Essays on Judaism, trans. Seán Hand (Baltimore, MD: Johns Hopkins University Press, 1990), 15; cf. Emmanuel Levinas, Totality and Infinity: An Essay on Exteriority, trans. Alphonso Lingis (Pittsburgh, PA: Duquesne University Press, 1969), 58.

92. Michael Wyschogrod, The Body of Faith: God in the People of Israel (San Francisco: Harper \& Row, 1989), 109.

93. Ibid., 107.

94. Ibid., 109-10. 
being but also for God's sake that "man is ... not simply a puppet in the hands of Hashem." If Kant, in Critique of Practical Reason, worried that knowledge of God's agency could turn human beings into mere puppets, for Wyschogrod, the possibility of God's agency, in fact, requires that human beings are no such things. For Wyschogrod, tension between the agency of God and human beings exists, then, not, as is the case for Kant-and Cohen and Levinas-because they are incompatible with one another, but rather because the two parties, God and human beings, are in fact in an actual relationship. The tension is an essential feature of this genuine and dialectically charged relationship from which the identities of both parties emerge.

The intractability of this dispute, then, is evidence for how hopelessly problematic the essentialistic fixation on authenticity is in so much twentieth-century Jewish philosophy. First, the effort to emphasize certain voices as authentically Jewish and to marginalize others as inauthentic, assimilationist, or syncretistic is inherently ideological and trades on essentialist conceptions of religion that have been rightly problematized in the last several decades of religious studies scholarship. Second, the effort to invoke the authentically Jewish, at least within modern Jewish thought, is itself rooted in a tacit privileging of Judaism over other religious traditions. It is no coincidence that as much as thinkers within both theocentrist and ethical monotheist camps disagree about the true or authentic essence of Judaism, they seem to nevertheless share the belief that this essence of Judaism corresponds to true or authentic religiosity as such. Thus, as different as the views of ethical monotheists are from the theocentrists, both camps offer a more or less exclusivist sense of Judaism amid a world filled with religious difference. What is in dispute is not this sense of exclusivism itself but rather the basis of it. Judaism's distinctiveness - from which flows its world historical significance-is either a result of its singular insistence on God's radical transcendence, or a result of the special relationship, the unique bond, between Israel and its God.

Hirsch's Die Religionsphilosophie der Juden, written well before any of these works of the twentieth century, combines strategies central to both ethical monotheists and theocentrists in its efforts to not only distinguish Judaism from all other religious traditions but to justify it in its difference. Hirsch claims that Judaism teaches a profound truth about God and human beings that is essential to a genuinely ethical existence, while simultaneously insisting that God maintains a unique covenant with the Jews to bear witness to this teaching for the rest of the world mired in paganism. To be sure, the profound truth that Judaism teaches, namely, that human beings possess a genuine capacity for freedom, entails that God's presence maintains a radical distance from the sphere of human activity. And yet, Hirsch claims both that God maintains a covenant with the Jews, and that this covenant ensures that the Jews will indeed promulgate this message of radical freedom to all of humanity. This covenantal relationship is presented in terms that are strikingly in tension with the view of God entailed by the very message to the nations which the Jews are to attest. If the prohibition against idolatry is rooted in the radical nature of human freedom, that no agency can inhibit the ability of human beings to determine and choose themselves, the idea of the 


\title{
Robert Erlewine
}

covenant is rooted in the inscrutable will of God, and is ultimately grounded in divine, not human, agency.

What is striking about Hirsch's thought is that while the three different strategies he employs to reconcile divine and human agency are each more or less coherent when taken individually, they are not coherent when taken together. In the twentieth century, we see two rival camps of thinkers crystalize around the poles of Hirsch's Die Religionsphilosophie der Juden, namely, the first and third strategies. ${ }^{95}$ The invocation of the authentically Jewish provides subsequent thinkers with a means to escape the contradictions between Jewish theological positions. By marking certain positions as inauthentic, as syncretist accretions or misbegotten efforts at assimilation, in the twentieth century, thinkers, whether theocentrists or ethical monotheists, maintain coherent positions in a way that Hirsch simply cannot.

However, arguments about authenticity can no longer be made with a good conscience. Fackenheim correctly perceived the contradictory nature of Hirsch's argument, but he drew the wrong conclusion from it. If Fackenheim understood this contradiction as exemplifying the incompatibility of authentic Jewish theology with modern (Kantian) philosophy, I have sought to present these contradictions as providing a vivid illustration that there is, in fact, a range of distinct, and often incompatible, strategies available to thinkers seeking to articulate Jewish theology in modern philosophical idioms. Die Religionsphilosophie der Juden will not help us settle the dispute between theocentrists and ethical monotheists. The internal contradictions of this text, however, can vividly illustrate the need to move beyond the misguided essentialist fixation on authenticity, and they can orient us towards the recognition that Jewish theology does not take up a single clearly distinguishable position but rather encompasses a range of diverse and often contradictory claims.

To be sure, much stands between Hirsch's work and the field of modern Jewish thought today. However, Hirsch's problem, that there are numerous ways to articulate Jewish theology in modern philosophical idioms without any good way for adjucating between them, has become once more our own. Rejecting the impetus to uncover the true nature or foundations of Judaism in favor of recognizing the multiplicity of ways Judaism has been constructed in the past and might be presented in the future surely makes modern Jewish thought more modest in its ambitions. However, it also fosters a certain sense of maturity, making its practictioners more attuned to questions of authority and ideology than has too often been the case.

\author{
Robert Erlewine \\ Illinois Wesleyan University
}

95. I do not mean to suggest by this that Hirsch is necessarily a direct influence on any or all of these thinkers. What is important is that various strategies he develops to articulate Judaism in the nineteenth century continue to be used in the twentieth. 